\title{
In God We Trust
}

James Tackett, (E-mail: JamesATackett@aol.com), Youngstown State University

Gregory A. Claypool, (E-mail: gregclaypool@yahoo.com), Youngstown State University

Fran Wolf, (E-mail: wolf1876@yahoo.com), Youngstown State University

\begin{abstract}
This case focuses on fraud and various elements of accounting and fraud examination practices and is appropriate for use in an upper division auditing course. The case is based on a true story - only the names have been changed.
\end{abstract}

\section{INTRODUCTION}

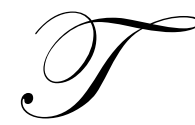

he Hope Center is a church owned and operated meeting and banquet facility capable of servicing about 500 people. The Center specializes in wedding receptions, graduations, religious ceremonies, etc. Approximately half of the Center's business comes from church members, and the remainder comes from educational, political, and private organizations. The Center has a modern kitchen, wine cellar, stage for live entertainment, dance floor, and several large rooms with audiovisual facilities. Annual revenues total approximately $\$ 900,000$, and there are seven full-time employees. The Center was built by the church, and has never had problems attracting business. However, profitability and cash flow difficulties have arisen in the last few years to a point where church funds were needed to support the Center. The church leadership assumed that profitability difficulties were caused by incorrect pricing, yet the prices charged by the Center were comparable to those of its competitors.

Monica Wilson is the manager of the Hope Center. Monica is an attractive 35-year-old college graduate with a degree in management, and she has been the manager for the last six years. The church leadership believed that Monica's "take charge" style was an asset in keeping everything under control at the Center. Monica is a "people person," and she has a special talent for pleasing the Center's clients and customers. Monica's greatest asset is her ability to attract and retain new business. However, Monica also had a dark side to her personality, and Center employees knew that she demanded absolute obedience. Any employee who failed to live up to Monica's expectations or questioned Monica's directives was promptly terminated.

As general manager, Monica had complete control over all aspects of the Center. She was in charge of hiring, selecting vendors and contractors, the day-to-day operations at the Center, and all recordkeeping and funds management. Monica was a member of the church, and had family ties to many church members. Most Center employees, customers, vendors, and contractors had some relationship with the church, and there was a general culture of trust between the church leadership and the Center. Accordingly, Monica had a "free hand" to run the Center without any interference from the church leadership.

\section{THE NEW ACCOUNTANT}

John Young was head of the Church Leadership Council, and he was personally responsible for hiring Monica as the general manager of the Center. After considerable discussion with other Council members, John decided it would be wise to separate the managerial and accounting responsibilities of the Center by hiring a fulltime accountant. John reasoned that the profitability difficulties of the Center were due to Monica spreading herself too thin by trying to personally manage all aspects of the Center. John also reasoned that Monica was a first-rate manager, but she was not an accountant, and perhaps this lack of accounting knowledge was one of the underlying causes of the Center's profitability difficulties. Accordingly, hiring a new accountant would allow Monica to focus on her true talents relating to marketing and managing the Center, while the new accountant would focus on the proper pricing of the Center's services. Additionally, hiring a new accountant would eliminate the need for any 
external accounting services that were being performed by a local CPA. This local CPA compiled unaudited financial statements for the Center from the financial information prepared by Monica.

When John met with Monica to tell her about the Council's decision to hire a new accountant, Monica strongly objected. Monica explained that she had taken an accounting course in college, and the money used to hire a new accountant would be better spent on radio and television advertising. Monica assured John that the profitability difficulties of the Center could be alleviated by bringing in new business at higher prices. John countered by explaining that the salary of the new accountant would be almost entirely offset by the savings from not having to employ an outside CPA. After much discussion and hard negotiating, Monica agreed to the hiring of a new accountant providing that he or she reported directly to Monica.

In three weeks, Carla Bishop was hired as the Center's new accountant. Carla is a Summa Cum Laude accounting graduate from the local university, and this was Carla's first full-time accounting position after graduation. John made the final decision in hiring Carla, but per the previous agreement, Carla reported directly to Monica. John explained to Carla that Monica was her immediate supervisor, but she could always come and talk to him if there were any problems between her and Monica.

From the very beginning, Carla could tell that Monica considered her an intruder. Monica's demeanor was polite and businesslike, but it seemed as though Monica was still holding on to the most important accounting records. The duties assigned to Carla were mostly customer and vendor data entry in Microsoft Access. Carla noticed that Monica controlled all cash deposits and disbursements as well as the supporting accounting records and bank reconciliations. Carla volunteered to accept wider responsibilities by managing the accounting records, but Monica declined her offer, and continued to assign her data entry and clerical duties. However, John insisted on receiving financial reports directly from Carla, so over time, Carla gained access to more and more of the accounting records. Yet, the accounting information available to Carla came directly from Monica.

\section{THE ANONYMOUS TIP}

After working at the Center for three months, Carla received an anonymous letter accusing Monica of stealing church funds. The letter contained enough details about Center activities to imply that its author had to be an employee of the Center. Carla reflected on her dilemma. In her heart, she believed the accusation could well be true. On the other hand, if she reported the anonymous letter to John Young, Monica was sure to find out, and Carla would likely have to start looking for another job. Carla decided to take the letter and her suspicions to John Young.

John was reluctant to accept the anonymous letter's charge. Yet, he was disturbed that his directive requiring the separation of accounting and management at the Center was being ignored by Monica. John and Carla talked for about two hours regarding Monica's complete domination of the Center. John asked Carla if she thought Monica was stealing. Carla paused for a moment, took a deep breath, and said yes. John's eyebrows raised, and he asked if she could prove that Monica was stealing. Carla said no, but she knew of someone at the university who specialized in this type of situation. John was reluctant to bring in an outsider, but Carla explained that she knew this person well (a former instructor and fraud specialist), and he could be trusted to operate within the discretionary limits of the church.

John agreed to meet secretly with Carla and Tom Burns to discuss the situation at the Center. Tom is a CPA and Certified Fraud Examiner who teaches fraud examination at the local university. John explained the need for a quiet investigation, and that any findings of impropriety must be kept in strictest confidence. Tom cautioned that the need for secrecy might render his findings inconclusive. John indicated that he would approve a wider investigation if there were proof that Monica was a thief, but until that time, the investigation must be kept secret. Tom agreed to the terms of the engagement. 


\section{THE INVESTIGATION}

The investigation began with a meeting between Tom and Carla in Tom's office at the university. Carla was working on her master's degree by taking evening classes, and this created an ideal meeting place that would be undetectable by Monica. Carla prepared an outline of the accounting and cash handling procedures at the Center, along with copies of the monthly financial statements for the past two years. Additionally, Carla prepared a gross profit analysis for each set of financial statements. The gross profit percentage fluctuated 15 to 20 percentage points from month to month. Tom asked how prices were determined for Center activities, and Carla replied that Monica set the prices, but she never revealed the method used for pricing. Tom ended their first meeting by requesting copies of the following information for the last two years:

1. Center bank statements.

2. Center's calendar of events.

3. Customer receipts.

4. The cash receipts and cash payments journal.

5. The payroll register.

After Carla left, Tom went to his computer to search the Internet for public records on Monica. The county auditor's website provided a property search function that gave Monica's address along with a description of her property. Tom noted that a building permit had recently been granted by the county, although he could not tell what the permit was for. Switching over to the clerk of courts website, Tom searched for any legal documents involving Monica Wilson. Tom noted the start of bank foreclosure proceedings on Monica's property five years earlier, but the legal proceedings were terminated for some unspecified reason.

The next day, Tom drove down to the records office and courthouse to examine the building permit and bank foreclosure documents. The building permit was for a new in-ground swimming pool in Monica's backyard. The foreclosure documents showed that the bank began foreclosure proceedings against Monica, but the proceedings were terminated when the bank received payment for overdue mortgage payments. Tom decided to drive by Monica's residence to see firsthand the current construction project. Monica's residence was well maintained with professional landscaping and elaborate flower gardens bordering all sides of the house. A landscaping service was there cutting the lawn, and Tom could see several pieces of large excavating equipment working in the backyard. Tom also noticed a late-model, silver Mercedes sedan parked in the attached garage.

Until now, all of the information gathered by Tom was free and publicly available. However, he decided to use a commercial records database to examine Monica's credit record. Such databases are available for professional fraud investigations. The bank's foreclosure proceedings were listed on her credit record, but her current credit rating was good. Also listed was an automobile loan for the Mercedes sedan that Tom saw in the garage.

In the meantime, Carla was having difficulty getting the documentation requested by Tom. With the exception of the calendar of events, all of these documents were kept under lock and key by Monica. Carla went to John Young for assistance. John and Carla went to the bank and secured copies of the Center's bank statements without difficulty. John also had a master key that would open any door at the Center, and he and Carla entered the Center in the evening when the parking lot was empty. When John tried to unlock the door to the records room, his master key would not work. Carla said she recalled seeing an invoice from a local locksmith just after she was hired.

The next day, John called the locksmith, and the locksmith confirmed that he had changed the locks on two doors at the Center on the orders of Monica. The locksmith prepared a duplicate key for John, and the next night John and Carla entered the previously inaccessible rooms of the Center. Using the copy machine, they made copies of the records requested by Tom. 
The following week, Carla and Tom spent an evening examining the Center's records. They noticed that the timing of bank deposits did not match the calendar of events. Frequently, there was a delay of two to four weeks between the time a Center event occurred and the time the corresponding funds were deposited at the bank. There was also the revelation that some carbon copies of customer receipts were significantly larger than the corresponding bank deposits. Approximately $75 \%$ of the customers paid by check, and the remaining $25 \%$ (usually church members) paid with cash. The cash payments journal showed cases of multiple payments to contractors for the same invoice. In several instances, payments to food vendors seemed excessive for the number of persons served at a given event. The payroll register showed recent paychecks issued to persons that Carla did not know.

Tom prepared a written report documenting the recordkeeping anomalies at the Center along with his observations regarding the bank foreclosure, swimming pool, and Mercedes. The following week, Tom met with John and Carla to discuss his findings. John and Carla were unaware that Monica owned a new Mercedes or that she was installing an in-ground swimming pool. Apparently, Monica always drove an older Volkswagen to work, and she said very little about her private life. Tom could tell by their facial expressions that these revelations registered more deeply with Carla than John Young. However, the discussion of discrepancies in the Center's accounting records brought tears to John's eyes. After recomposing himself, John asked Tom if Monica was a thief. Tom explained that the fraud examiner's code of ethics prohibited him from expressing an opinion on the guilt or innocence of a person, and only the courts can make that judgment. However, he is concerned about these discrepancies, and he believes that a deeper investigation is warranted. John asked Tom how to proceed, and Tom said he would like to meet with Monica alone to discuss the Center's recordkeeping practices.

John suggested that he should be present when Tom interviewed Monica, but Tom said this was a bad idea because he wanted to employ the "Reid Technique." Tom explained that the Reid Technique was a scientific method for interviewing persons suspected of misconduct, and it maximized the likelihood of finding the truth in an interview setting. Tom further explained that John's presence at the interview could make the Reid Technique less effective, and Monica would be less likely to admit wrongdoing if John were there. John agreed to allow Tom to interview Monica alone.

Tom indicated that Monica should not be told about the impending interview. He explained that in this particular set of circumstances, i.e., very strong evidence of serious misconduct, a "surprise interview" would be most effective. However, John felt it would be morally wrong to subject Monica to this interrogation without giving her ample time to collect her thoughts and prepare a defense. Tom was unsuccessful in persuading John to agree to a surprise interview, so he agreed to interview Monica the following Monday which would give her the weekend to prepare.

\section{BURNING THE BOOKS}

The next day, John called Monica to his office to explain the coming interview. He said that someone had complained about the recordkeeping methods used at the Center, and the Leadership Council felt it was best to eliminate any charges of impropriety with an investigation. John further explained that this investigation would preserve the image of the church, and she should give her full cooperation. Monica sat in stunned silence for an extended period, and then asked, "Who made the charge? Was it Carla?" John assured her that it was not Carla, but he was unable to reveal the exact nature of the charge or the person who brought the complaint to his attention. Monica said that she did not understand why the Council would authorize an investigation without any evidence. Monica then asked, "Is there any evidence that I've done something wrong?" John ignored her question.

Monica maintained her composure until she found out that the church had retained a professional examiner to conduct the investigation. She told John that she would be happy to show him all of the Center records right now, but she felt deeply hurt that the Council would bring in an "outsider" without first discussing these accusations with her. With considerable sarcasm, Monica asked John to name the person who would be conducting the "Inquisition." John said it was a local accountant, and there would only be routine accounting questions. Monica rolled her eyes and shook her head. John looked directly at Monica, and asked her if there was anything he should know about? Monica instantly snapped, "Absolutely not! I have nothing to hide, and there is nothing wrong at the Center." John 
said this was good news, and therefore she had nothing to fear. Monica stormed out of John's office saying, "Fine, I'll be ready by Monday morning."

John arrived at the church Saturday morning to prepare for weekend services. Across the street, John noticed a fire at the barbecue pit of the Center picnic grounds. John settled down to work in his office, and a short time later, he received a phone call from Wanda who was the head cook at the Center. Wanda apologized for bothering him, and she asked if he knew that many Center records were being burned by Monica? John asked, "What kind of records?" Wanda said that she was not sure, but they appeared to be the Center's accounting records. John hurriedly walked across the street and into the Center.

John asked, "Where is Monica?" The janitor pointed to the back door which was adjacent to the picnic area. John walked out into the picnic area, and he could see Monica throwing documents into the fire. Monica was unaware of John's presence as he approached, and she was startled as he quietly stepped beside her.

John said, "What are you doing Monica?" After catching her breath, Monica said she was just cleaning her office in preparation for Monday. John picked up several of the documents that were going to be thrown into the fire and noted that they were for a banquet given by the Center just a few weeks ago. John said, "These documents are from last month, why would you be burning them?" After a long moment of silence, Monica said the single word "duplicates." Monica further explained that her office was cluttered, and she was getting rid of duplicate records so that everything would be ready for Monday. John commented that these documents appeared to be originals, and if these were duplicates, could he please see the originals. Monica replied that Carla had the originals per his previous directive. John looked squarely into Monica's eyes and said that she needed to tell the truth. Monica shouted, "That's it, I'm out of here! If my word means nothing to you, then I shouldn't be working here." John replied in a calm but firm voice, "I want your keys."

Monica handed John her Center keys, and she walked straight to her Volkswagen and drove away without looking back or taking anything with her. John never spoke to Monica again. When John entered Monica's office, it was cleaned out. All of her personal possessions were gone, and there were no records of any kind. John called Carla to come in and assist him, and a careful search of the Center revealed that the only surviving records were the small amount that John prevented Monica from burning in the grill.

\section{EPILOGUE}

After Monica was fired, several employees of the Center came forward and told of systematic pilfering of food and wine by Monica. Boxes of steak, lobster, caviar, $\$ 100$ bottles of wine, etc. were routinely taken by Monica. Special discounts were given to Monica's friends and relatives, and Monica issued paychecks to her relatives even though they never worked at the Center. Moreover, duplicate payments to certain vendors appeared so frequently that the possibility of human error must be excluded. The same vendors never received 1099s from the Center, which enabled them the opportunity to avoid declaring Center payments as income.

Based on his copies of Center records, Tom Burns estimated the Center's total loss at between $\$ 200,000$ and $\$ 300,000$. John Young accepted responsibility for the loss, and offered his resignation to the Leadership Council. The Council declined John's resignation, and John hired a replacement for Monica. Profitability returned to the Center, and there was even enough left over for significant charitable contributions. Carla worked with John to develop proper internal controls for the Center, and she continued as the Center's accountant until she received her MBA and CPA certificate. Today Carla has her Ph.D., and she teaches accounting at a state university. Monica filed for bankruptcy and moved out of state. She was never prosecuted because much of the evidence against her was burned, and the photocopies made by John and Carla were legally suspect in court under the best evidence rule. In addition, John believed that an open trial would have severely damaged the church. 


\section{CASE QUESTIONS}

\section{Question 1}

Dr. Donald Cressey developed the Fraud Triangle to analyze fraud scenarios. The Fraud Triangle says that fraud occurs when there is psychological pressure, opportunity to commit the fraud, and rationalization to justify the fraud in the perpetrator's mind. Discuss the elements of the Fraud Triangle that appear in this case.

\section{Answer To Question 1}

The pressure element appears to have originated when the bank began foreclosure proceedings on Monica's house. Unable to meet her mortgage payments, Monica began skimming funds from the Center. Later on, Monica's desire for a high standard of living, e.g., swimming pool, Mercedes, expensive food, etc., further contributed to the pressure element of the Fraud Triangle.

The opportunity element occurred because of her complete domination and control of the Center. Personally maintaining the accounting records, and controlling the custody of cash receipts, enabled Monica to skim money from the Center without detection. Exacerbating this serious violation of internal control, was the element of "trust" between the Center and the church. Normal internal controls were not in place because the implementation of such controls would have created the appearance of mistrust, which was psychologically unacceptable to the church leadership.

The rationalization element requires some speculation because Monica never admitted wrongdoing, or articulated what was in her mind to justify the fraud. In all likelihood, she believed that her hard work and talent made the Center a success, and she believed that she was entitled to appropriate compensation beyond her modest salary.

\section{Question 2}

"Red flags" are clues that should have alerted overseers to the possibility of misconduct. Some red flags were available to John Young, while other red flags could only have been recognized by a trained accountant. Discuss the red flags that should have told John that something was amiss at the Center. Discuss the red flags that Tom Burns would have noticed in his investigation.

\section{Answer To Question 2}

There are several observations that should have alerted John to the possibility of misconduct. First, the prices charged by the Center were similar to its competitors, yet the Center was experiencing financial difficulties. John should have noted this clue and looked more deeply at the situation while keeping an open mind. Second, Monica's strong opposition to hiring a full-time accountant should have aroused John's suspicions. Finally, Monica's changing of the locks at the Center without notifying John should have heightened John's awareness of sinister possibilities, and he should have allowed Tom Burns to proceed with the surprise interview.

Tom Burns undoubtedly noticed Monica's excessive lifestyle, e.g., swimming pool, Mercedes, landscaping services, etc. which was unsupportable by her salary. John cannot be faulted for missing this clue because Monica cleverly hid her extravagance from him. Tom would have also recognized the gross profit fluctuations as a possible skimming or larceny scheme. Similarly, the delayed bank deposits and mismatching of bank deposits with the calendar of events would have also suggested the possibility of fraud. Having persons on the payroll that were unknown to Carla would have implied the possibility of ghost employees. 


\section{Question 3}

Discuss the mistakes that John made in resolving the case.

\section{Answer To Question 3}

John seemed unaware of Monica's dark side, and that Center employees were afraid of her. A supervisor should always spend some time talking to rank-and-file employees to properly understand their work environment. If John had maintained better relations with some of the Center employees, someone may have stepped forward earlier regarding Monica's improper behavior.

After retaining Tom Burns, John interfered with his investigation by preventing Tom from performing a surprise interview of Monica. John's warning to Monica about the impending interview enabled her to destroy much of the evidence that would have been used against her. In a surprise interview, Monica would have had little time to respond in a way other than an admission of guilt, and the burning of records would have been prevented.

\section{Question 4}

Given the facts in this case, speculate on how Monica perpetrated the fraud.

\section{Answer To Question 4}

Twenty five percent of the Center's clients paid in cash. Monica pocketed the cash, and delayed the deposit of other payments by check in order to give the appearance of bank deposits for each of the functions listed in the calendar of events. However, payments to food vendors and part-time employees had to be made in real-time, which meant the costs were real but the revenues varied significantly according to the amount of money skimmed in a given month. This explains the fluctuating gross profit percentages, and the customer receipts that were larger than the corresponding bank deposits. Monica made a clear mistake by giving customer receipts for cash payments without preparing fictitious carbon copies to reflect the amounts that would actually be recorded in the books and on the bank statements.

The multiple payments to selected contractors without corresponding 1099s suggest the possibility of a kickback scheme, although this was never actually proven. Since Monica controlled the Center payroll, it was easy for her to write paychecks to her relatives for work that was never done. Monica apparently ordered extra food and wine inflating costs and then took the excess for herself rather than have it "go to waste."

When Monica was caught burning the records, her office was already cleaned out which implies that she never intended to show up for Monday's interview with Tom Burns. She recognized that she could not survive the interview, so she destroyed as much evidence as possible.

\section{Question 5}

Discuss some internal controls that would have been beneficial for the Center.

\section{Answer To Question 5}

John was correct in seeking a separation of accounting and managerial duties at the center. Monica was able to perpetrate this fraud because she had simultaneous access to assets and accounting records. She could therefore steal the assets, and then doctor the accounting records to hide the theft. Proper internal controls at a small business like the Center would include separating the accounting, cash handling, and management functions. Carla should have done the accounting, John could have controlled all cash receipts and signed all checks, and the Manager would have been responsible for everything else. Carla could have done the bank reconciliation based on John's expenditure report. All payments to the Center should be made by check, cash receipts should be deposited 
daily, and payments from the Center should not be made to employees or vendors without authorization from the Manager and John.

\section{NOTES}

